\title{
De impact van multi- level governance op de democratische input in het EU-handelsbeleid onder het Verdrag van Lissabon
}

Fabienne Bossuyt

\section{ABSTRACT: The Impact of Multi-level Governance on Democratic Input in EU Trade Policy under the Lisbon Treaty}

This article examines the impact of multi-level governance (MLG) on the democratic input into European Union (EU) trade policy under the Lisbon Treaty. Focusing on two recently concluded EU trade agreements, i.e. the multi-party agreement with Colombia and Peru and the association agreement with Central America, the article traces several dangers and risks that MLG entails for democratic accountability and participation, which are closely tied to the strong output-oriented nature of MLG and its emphasis on technical efficiency. These dangers of MLG - the article argues - are not accidental, but are firmly rooted within an underlying hegemonic social-economic trend, characterised by an intentional (neo-liberal dominated) attempt to de-politise, and even de-democratise, European political policy-making.

KEYWORDS: multi-level governance, subsidiarity, EU trade policy, legitimacy, participation

\section{Inleiding}

Dit artikel onderzoekt de impact van multi-level governance (MLG) op de democratische input in het EU-handelsbeleid onder het Verdrag van Lissabon en vertrekt daarbij vanuit de vaststelling van Peters en Pierre (2004, p. 75) dat er behoefte is aan een kritische discussie van MLG als een democratisch proces. Zowel in de literatuur als door beleidsmakers wordt aangenomen dat het Verdrag van Lissabon 
het democratische gehalte van het EU-handelsbeleid versterkt, namelijk door het Europees Parlement meer wetgevende bevoegdheid te geven inzake handel (zie bv. Kleimann, 2011; Woolcock, 2010). Dit artikel nuanceert deze aanname en problematiseert de algemene stelling dat het democratische deficit met betrekking tot het handelsbeleid verkleint door de institutionele hervormingen die onder het Verdrag van Lissabon zijn doorgevoerd. Die hervormingen waren namelijk hoofdzakelijk gericht op het verhogen van de 'efficiëntie' van het (neo-liberaal geïnspireerde) EUhandelsbeleid. Dat het Europees Parlement meer parlementaire controle verwierf moet in dit opzicht gezien worden als een noodzakelijk gevolg eerder dan als een doel op zich. Er heerste slechts één prioriteit: de bevoegdheid voor handel moest volledig worden overgeheveld naar het EU-niveau, weg van de (sub)nationale parlementaire controle, met als inzet een verhoogde efficiëntie van het gemeenschappelijk handelsbeleid.

Dit artikel ziet in deze recente ontwikkeling een rechtstreeks verband met enkele meer diepgaande factoren die ingebed zijn in het meerlagige bestuurssysteem van de EU, in de Angelsaksische literatuur geconceptualiseerd als multi-level governance (o.a. Bache \& Flinders, 2004b; Hooghe \& Marks, 2001). De traditionele conceptualisering ziet MLG als "een vernieuwde, efficiënte, gedecentraliseerde bestuursvorm die op een haast natuurlijke wijze uit het Europees integratie- en binnenlands federaliseringproces is totstandgekomen” (Devos, 2001, p. 87). In navolging van kritische auteurs binnen de MLG-literatuur (bv. Peters \& Pierre, 2004, p. 75) nemen wij echter aan dat MLG als bestuurssysteem gevaren en risico's inhoudt voor democratische verantwoording en participatie in het bestuur. Een specifiek gevaar schuilt in het sterk 'output'-gerichte karakter van MLG en de nadruk op technische efficiëntie. Dit heeft op zijn beurt consequenties voor de toepassing van het subsidiariteitsbeginsel, dat moet garanderen dat Europese politieke kwesties beslist worden op het meest efficiënte politieke niveau. Het gevaar dreigt ook dat multi-level 'governance' in de praktijk neerkomt op multi-level 'participatie', wat inhoudt dat er wel een grotere betrokkenheid is van niet-statelijke actoren (zoals vakbonden en ngo's), maar geen effectieve invloed. Tegelijkertijd is er een vervaging merkbaar van de scheiding tussen publieke actoren en private actoren, met name door het creëren van netwerken met belangengroepen die betrokken worden bij de totstandkoming van het EU-beleid.

Om de impact en dynamieken van deze gevaren en risico's van MLG te begrijpen is het belangrijk om ze te plaatsen binnen de bredere politico-ideologische context van dit bestuurssysteem. Deze gevaren zijn namelijk geen toevalligheden, maar ze zijn onlosmakelijk verbonden met de vaststelling dat MLG een impliciete normatieve dimensie heeft. MLG kadert immers in een hegemonisch politiek-ideologisch discours en denken, dat is voortgekomen uit de overgang van het fordisme naar het post-fordisme, of de overgang van "de rigide, nationale Keynesiaanse welvaartsstaat naar de flexibele en post-nationale Schumpeteriaanse workfarestaat”, 
een transformatie "waarvan flexibilisering en de desintegratie van de nationale constellatie essentiële onderdelen vormen” (Devos, 2001, p. 87; zie ook Harmes, 2006). In het hegemonische discours en denken ligt de nadruk op samenwerking ten koste van sociale strijd en conflict, op efficiëntie ten koste van inspraak en op netwerken ten koste van formele instellingen.

Dit discours en denken verbergt echter fundamenteel tegengestelde belangen en antagonismen en niet in het minst de sociale conflicten die eigen zijn aan de klassieke strijd tussen kapitaal en arbeid (Devos, 2001). Dit helpt om aan te tonen dat MLG, als een meerlagige opbouw van politieke processen, niet machtsneutraal is, maar gepaard gaat met empowering/disempowering-processen. Concreet betekent dit dat de beslissing "in welke mate op welk niveau de who gets what when and how vraag beslecht wordt geen louter door efficiëntie ingegeven beslissing is, maar onvermijdelijk politiek relevante gevolgen heeft in termen van de machts(her)verdeling tussen sociale actoren met uiteenlopende middelen, desiderata, agenda's, etc.” (Devos, 2001, p. 90).

Het artikel past deze kritische benadering ten aanzien van MLG toe op het EU-handelsbeleid. Het onderzoek richt zich daarbij op twee recentelijk afgesloten vrijhandelsakkoorden, met name het akkoord met Colombia en Peru en het handelsluik van het associatieakkoord met Centraal-Amerika. Om ook het niveau van de (sub)nationale parlementen te kunnen bestuderen wordt op lidstatenniveau gekeken naar vijf lidstaten, namelijk Duitsland, het Verenigd Koninkrijk, België, Ierland en Nederland.

Het artikel is als volgt opgebouwd. Na deze inleiding maken we gebruik van inzichten uit kritische theorieën om de 'risico's' en 'gevaren' van MLG als een democratisch proces uit te diepen. Om deze gevaren en risico’s concreet te schetsen kijken we daarna enerzijds naar de impact van MLG op maatschappelijke participatie en anderzijds naar de impact op parlementaire controle en inspraak. We belichten hierbij ook wat precies de consequenties zijn voor de toepassing van het subsidiariteitsbeginsel binnen het handelsbeleid van de Unie. Daarna onderzoeken we de democratische input in de multipartiete handelsovereenkomst met Colombia en Peru en het biregionale akkoord met Centraal-Amerika. Om dit te doen kijken we opnieuw enerzijds naar maatschappelijke participatie en anderzijds naar parlementaire inspraak, en dit zowel tijdens als na de onderhandelingen. Het artikel wordt afgesloten met enkele slotopmerkingen op basis van de belangrijkste onderzoeksresultaten.

\section{Kritische discussie van MLG als democratisch proces}

Het artikel vertrekt vanuit de vaststelling van Peters en Pierre (2004, p. 75) dat er behoefte is aan een kritische discussie van MLG als een democratisch proces. 
Onze studie volgt dan ook hun assumptie dat MLG als bestuurssysteem gevaren en risico's inhoudt voor democratische verantwoording en participatie in het bestuur. Kritische vragen rond de impact van MLG op de democratische input in het EU-bestuur vloeien voort uit de bezorgdheid dat de bevoegdheidsoverdraging naar het EU-niveau niet gepaard gaat met een evenredige uitbouw van de nodige politico-institutionele voorzieningen voor parlementaire controle en de democratische verantwoording die besluitvormers dienen af te leggen (Bovens, Curtin \& 't Hart, 2010; Bursens \& Baetens, 2006). Volgens Peters en Pierre (2004, p. 85) dreigen de problem-solving-capaciteit van MLG en het bereiken van doeltreffende beleidsresultaten voorrang te krijgen op democratische inspraak en verantwoording.

\subsection{Kritische blik op Europese integratie: de EU als een proces van de-democratisering}

Kritische perspectieven binnen het debat over het democratische deficit van de EU stellen dat de Europese integratie een proces is dat gekenmerkt wordt door een uitdrukkelijke poging om de Europese politieke besluitvorming te depolitiseren, of anders gezegd te ‘de-democratiseren’ (Bonefeld, 2001; Mair, 2005; 2007). Zo argumenteert Rancière (2006, pp. 81-82) dat supranationale integratie dient om "politieke zaken te depolitiseren en te behouden voor plaatsen die niet-plaatsen zijn, plaatsen die geen enkele ruimte laten voor de democratische uitvinding van polemiek en contestatie”. Via de verplaatsing van de besluitvorming naar het supranationale niveau, waar democratische participatie geconfronteerd wordt met verschillende obstakels, slagen de Europese politieke elites erin om de ruimte voor (mogelijk tegenwerkende) democratische participatie te beperken (Bailey, 2010).

Vanuit een neomarxistische invalshoek is dit proces van de-democratisering onlosmakelijk verbonden met de marktgerichte, neoliberale agenda die domineert op het EU-niveau. Zo beschouwt Bailey (2010) de EU als een poging van de Europese politieke elite om haar greep op de Europese maatschappij veilig te stellen door het toepassen van een gede-democratiseerde vorm van democratie die grotendeels bestuurd wordt door de bevordering van het marktmechanisme als basisbeginsel voor de regulering van sociale interactie. Opdat dit technocratische model van marktgericht bestuur zou werken, moet democratische participatie in of mobilisering tegen dit mechanisme beperkt blijven. Volgens dezelfde neomarxistische logica creëert de centrale focus op marktliberalisering van de EU de nood om marktuitwisseling en liberalisering uit te breiden buiten de EU (Baily \& Bossuyt, 2012; Boyer, 2011; Streeck, 2011). Zonder verdere marktuitbreiding - en dus zonder de voordelen die zo'n marktexpansie kan opleveren - zou het beginsel van 
marktuitwisseling niet (of minder) kunnen dienen om sociale interactie te stimuleren, waardoor het geproblematiseerd zou worden als middel voor regulering van sociaal gedrag. Als de EU zich in stand wil houden als een gede-democratiseerd, marktgericht bestuurssysteem, dan dient dus ook het marktuitbreidingsproces dat gerealiseerd wordt door het gemeenschappelijk handelsbeleid - voldoende gedepolitiseerd te worden (voor een discussie over depolitisering, zie bv. Shields, 2011). Volgens deze redenering kunnen we verwachten dat het EU-handelsbeleid, dat onder druk staat om marktexpansie te realiseren, evenzeer gekenmerkt wordt door een proces van depolitisering, waarbij de Europese politieke elites proberen om democratische participatie in en maatschappelijke mobilisering tegen het EUhandelsbeleid te vermijden of op zijn minst te beperken (Bailey \& Bossuyt, 2012, zie ook van Apeldoorn in dit nummer van Res Publica).

\section{2. 'Jumping of scales': de machtsverdelingseffecten van MLG}

Devos (2001) en Harmes (2006) gaan verder in op dit proces van de-politisering en de-democratisering door gebruik te maken van de 'jumping of scales'-theorie (het verspringen van beleidsniveau/schaal). De verhouding tussen de 'schalen' of bestuursniveaus is geen natuurlijk gegeven maar het gevolg van eerdere sociale verhoudingen en strijd, niet in het minst tussen kapitaal en arbeid (zie ook Oosterlynck in dit nummer van Res Publica). "De machtsverdelingeffecten die de mobiliteit van kapitaal, goederen en sommige diensten en de hypermobiliteit van informatie over verschillende schalen met zich meebrengen ontstaan louter door de ongelijkheid inzake mobiliteit, doordat sommige sociale groepen relatief immobiel zijn, zich m.a.w. op een andere - in regel 'hogere' - schaal veel moeilijker kunnen organiseren” (Devos, 2001, p. 91). Concreet betekent dit dat ondernemingen en belangengroepen macht onttrekken uit de relatief grotere mobiliteit die ze hebben over verschillende schalen in vergelijking met werknemers en vakbonden, die relatief verankerd zitten op het (sub)nationale niveau.

Net als Devos (2001) plaatst Harmes (2006) MLG binnen een bredere, mondiale tendens die gerelateerd is aan de transformatie naar de post-fordistische economie, waarin neoliberale en progressieve sociale krachten tegenover elkaar staan. Harmes (2006) ziet in MLG een proces waarbij neoliberale beleidsmakers en denkers strijd leveren ten voordele van verdere handelsliberalisering. Ze doen dit door enerzijds economische, marktbevorderende aangelegenheden zoveel mogelijk over te hevelen naar het supranationale niveau en anderzijds sociale, marktbeperkende zaken zoveel mogelijk op het (sub)nationale niveau te houden. De logica hierachter is dat 'economie' dient te worden gescheiden van 'politiek' via een verticale as, waarbij economische aangelegenheden altijd op minstens één hoger beleidsniveau moeten worden bestuurd dan marktbeperken- 
de zaken om zo een neoliberale vooringenomenheid te kunnen inbouwen in het (sub)nationale niveau. Door de 'exit-optie' die ondernemingen hierdoor genieten ontstaat een situatie van competitieve deregulering tussen (sub)nationale overheden: ondernemingen kunnen aan 'regime shopping' doen en (sub)nationale overheden tegen elkaar uitspelen door te dreigen het grondgebied te verlaten als de (sub)nationale marktbeperkende regelgeving verstrengd wordt (Harmes, 2006, p. 743). Terwijl kapitaal (individuele ondernemingen en belangroepen) bevoordeeld wordt op het supranationale niveau dankzij zijn relatieve mobiliteit, zit arbeid (werknemers en vakbonden) vast op het (sub)nationale niveau, dat ondanks de marktbeperkende bevoegdheden geen dreiging vormt voor verdere handelsliberalisering, omdat de respectievelijke overheden niet gebaat zijn met het doorvoeren van strengere marktbeperkende regelgeving, ten minste als ze willen concurreren met andere lidstaten (of regio's) om bedrijven te behouden of aan te trekken.

Hieronder geven we aan hoe deze inzichten uit de kritische literatuur zich concreet vertalen met betrekking tot de impact van MLG op de democratische input in het EU-bestuur in het algemeen en, vervolgens, in het EU-handelsbeleid meer specifiek.

\subsection{Impact van MLG op parlementaire inspraak en maatschappelijke participatie}

Om de gevaren en risico's te schetsen die MLG als bestuurssysteem inhoudt voor democratische inspraak in het bestuur kijken we enerzijds naar de impact van MLG op maatschappelijke participatie en anderzijds naar de impact op parlementaire controle en inspraak.

\subsubsection{Maatschappelijke participatie}

Bache en Flinders (2004a, p. 205) waarschuwen dat participatie binnen de context van MLG niet automatisch macht betekent. Hiermee willen ze erop wijzen dat de opkomst van MLG als het heersende bestuurssysteem van de EU niet noodzakelijk ten goede komt van de zwakkere maatschappelijke groepen en dat MLG de macht concentreert in de handen van die groepen en actoren die over de nodige middelen beschikken om heel doeltreffend te kunnen werken in een complexe context. Peters en Pierre (2004, p. 87) halen twee kenmerken aan van MLG die volgens hen vragen doen rijzen over het vermogen en de wil van de bestuurders om binnen het MLG-systeem voldoende gehoor te geven aan de belangen van de zwakkere sociale actoren, met name het gebrek aan een duidelijk regelgevend kader voor instituti- 
onele contacten en het gebruik van informele onderhandelingen en netwerken. De auteurs wijzen op het gevaar dat multi-level 'governance' in de praktijk niet veel meer betekent dan multi-level 'participatie'. Daarmee bedoelen ze dat maatschappelijke actoren wel betrokken worden bij het beleid, maar dat ze niet noodzakelijk een effectieve invloed of noemenswaardige inspraak hebben. Deze these werd bevestigd in recente studies, die specifiek nagingen of niet-statelijke actoren, waaronder ngo's en commerciële belangengroepen, hun stem kunnen laten horen op het EU-niveau (Dür \& De Bièvre, 2007; Hannah, 2011; Jarman, 2008; Trommer, 2011). Of een maatschappelijke actor al dan niet invloed kan uitoefenen op het EU-niveau, blijkt enerzijds af te hangen van zijn organisatorisch (lobby)vermogen en anderzijds van de mate waarin zijn belangen overeenstemmen met die van de supranationale actoren.

Tegelijkertijd is er een vervaging merkbaar van de scheiding tussen publieke actoren en private actoren. Binnen het MLG-systeem uit zich dit onder meer in het creëren van informele netwerken met belangengroepen die actief betrokken worden bij de totstandkoming van het EU-beleid. Om terug te keren op de neomarxistische logica die we hierboven beschreven hebben, kan vastgesteld worden dat de EU in het bestendigen van haar marktexpansie nauwe banden onderhoudt met exportgerichte belangengroepen, die een bevoorrechte participatie genieten die niet evenredig is met de inspraak die andere maatschappelijke actoren krijgen (Dür, 2008b; Siles-Brügge, 2010). Dit sluit aan bij het argument van Devos (2001) en Harmes (2006) dat kapitaal in het MLG-systeem bevoordeeld wordt dankzij zijn relatieve mobiliteit en zijn vermogen om op verschillende niveaus (lobby) middelen in te zetten, in tegenstelling tot arbeid die relatief verankerd zit op het (sub)nationale niveau en niet over de capaciteit beschikt om het EU-niveau danig te beïnvloeden.

\subsubsection{Parlementaire inspraak}

Een ander gevaar voor het democratische gehalte van MLG schuilt in het sterk 'output'-gerichte karakter van MLG en de nadruk op (technische) beleidsefficiëntie, wat ten koste dreigt te gaan van legitimiteit. Inderdaad, volgens Peters en Pierre (2004, p. 85) dreigen de problem-solving-capaciteit van MLG en het bereiken van doeltreffende beleidsresultaten voorrang te krijgen op democratische inspraak en verantwoording. De kernwaarden van democratisch bestuur dreigen te worden ingeruild voor accommodatie, consensus en efficiëntie, waarbij informele patronen van politieke coördinatie mogelijk een strategie zijn voor politieke belangen om het soort regelgeving te omzeilen dat net de taak heeft om zoiets te voorkomen. Kortom, het gevaar dreigt dat via MLG getracht wordt om de formele bestuursstructuren te omzeilen die centraal 
hebben gestaan bij klassieke bestuursvormen (2004, p. 88). Greven (2005) wijst erop dat supranationale politieke regimes de ideale omstandigheden bieden voor informele besluitvorming en problem-solving, waarbij networking, onderhandelen en informele coördinatie centraal staan. Greven toont op een heel overtuigende manier aan hoe de dynamieken van die informele politieke processen erin slagen de vereisten voor verantwoord en legitiem bestuur te omzeilen. Terwijl 'informalisering' bedoeld is om de problem-solving-capaciteit en doeltreffendheid van supranationale bestuurssystemen te verhogen, en daar vaak ook in slaagt, tast het tegelijkertijd de transparantie, verantwoording en dus legitimiteit van de Europese politiek aan (Greven, 2005, p. 264).

Perraton en Wells (2004) merken in hun studie over MLG en Europees fiscaal beleid een dergelijke trade-off op tussen democratische participatie en verantwoording en efficiëntie. Binnen fiscaal beleid heerst namelijk de overtuiging dat een verhoogde (maatschappelijke) participatie in gecentraliseerde bestuurssystemen nadelig zou zijn voor economische efficiëntie (2004, p. 182). Terwijl er weinig bewijzen voor handen zijn om deze hypothese te ondersteunen of te weerleggen, blijkt het wel zo te zijn dat de vorm van politieke instellingen op verschillende bevoegdheidsniveaus, en in het bijzonder maatschappelijke participatie in die instellingen, een invloed kan hebben op de efficiëntie. Maar zoals reeds heel wat studies hebben aangetoond is het moeilijk om de juiste balans te vinden tussen verantwoording en efficiëntie (Bellone \& Goerl, 1992; Moe, 1994; Oughton, 1995; Roth, 1996).

Bache en Flinders (2004a, p. 204) leiden hieruit af dat het grootste probleem in de context van MLG (een gebrek aan) legitimiteit is. Terwijl MLG in zijn verschillende vormen kan bijdragen tot de legitimiteit van het overheidsbeleid door een verhoogde efficiëntie, kan het de legitimiteit - in de vorm van democratische verantwoording - beperken, tenzij er nieuwe manieren worden gevonden om de mensen meer in verbinding te brengen met de veranderende machtsstructuren.

De discussie rond de trade-off tussen democratische input en efficiëntie houdt rechtstreeks verband met de toepassing van het subsidiariteitsbeginsel, dat moet garanderen dat Europese politieke kwesties beslist worden op het meest geschikte politieke niveau. Volgens de standaarddefinitie van subsidiariteit dient dit beginsel om te kunnen oordelen over een geschikte bevoegdheidsverdeling: beleidskeuzes moeten zo dicht mogelijk bij de burger gemaakt worden om de democratische legitimiteit te garanderen en mogen enkel naar een hoger bestuursniveau overgedragen worden als dat niveau meer efficiënt en doeltreffend is om de beleidsdoelstelling te bereiken (De Ville, 2012). Hieronder bekijken we wat precies de consequenties zijn voor de toepassing van het subsidiariteitsbeginsel binnen het gemeenschappelijk handelsbeleid van de Unie. 


\subsection{MLG en handelsbeleid: efficiëntie versus democratische input/legitimiteit}

In het EU-handelsbeleid draait de discussie over subsidiariteit vooral om het antwoord op de heikele vraag hoe de efficiëntievoordelen van vrijhandel dienen te worden verenigd met het recht van de regionale, nationale en subnationale overheden om normatieve en sociale doelstellingen na te streven, waaronder milieubehoud, gezondheids- en consumentenbescherming, welvaartsherverdeling, sociale zekerheid en arbeidsnormen (De Ville, 2012). De vraag die rijst is wie er op welk niveau het meest geschikt is om over deze trade-off beslissingen te maken (De Ville, 2012). Het subsidiariteitsbeginsel leent zich niet tot een gemakkelijk antwoord op deze vraag, niet in het minst gezien de afweging die het veronderstelt tussen legitimiteit en efficiëntie (supra). Terwijl het internationale niveau logischerwijze het meest adequate is om het doel van vrijhandel te bereiken, zijn lagere bestuursniveaus vaak meer geschikt om normatieve en sociale doelstellingen te verwezenlijken of zijn ze het meest legitiem omdat preferenties tussen maatschappijen vaak te veel verschillen om op internationaal niveau een consensus te vinden (De Ville, 2012).

Problematischer is echter dat er een institutionele discrepantie ingebed zit in het huidige MLG-systeem tussen enerzijds bevoegheden over marktbeperkende (in het bijzonder sociale) maatregelen en bevoegheden over marktbevorderende maatregelen, die grotendeels ingegeven zijn door het neoliberale hegemonische denken dat vandaag het Europese politieke landschap domineert (supra). Op basis van het subsidiariteitsbeginsel mag het volkomen verantwoord lijken dat het EUniveau steeds meer beleidsbevoegdheid heeft verworven over marktbevorderende aangelegenheden, terwijl de bevoegdheid over marktbeperkende zaken (en vooral over sociaal beleid) op het (sub)nationale niveau blijft. Dit verbergt echter de destructieve neoliberale vooringenomenheid die ingebouwd zit in het MLG-systeem en die het steeds moeilijker maakt voor het (sub)nationale niveau om zich op te stellen als de hoeder van de welvaartstaat (supra) (zie ook Wigger in dit nummer van Res Publica).

Omwille van de doeltreffendheid en efficiëntie die het hoogste bestuursniveau garandeert voor handelsliberalising, is handelsbeleid reeds sinds de start van het Europese integratieproces een supranationale bevoegdheid binnen de EU, waarbij de Unie gaandeweg meer exclusieve bevoegdheid heeft verworven over het handelsbeleid. Die evolutie culmineerde met het Verdrag van Lissabon, dat ervoor zorgde dat het handelsbeleid nagenoeg volledig is ondergebracht bij het supranationale niveau. De EU is nu exclusief bevoegd over handel in goederen en in diensten, de commerciële aspecten van intellectueel eigendomsrecht en investeringen. Deze verdere bevoegdheidsoverdracht stoelt op de overtuiging dat de lagere bestuursniveaus minder efficiënt zijn om beslissingen te nemen over handelslibe- 
ralising, waarbij vaak wordt verwezen naar de geringe interesse die (sub)nationale parlementen blijken te hebben voor handelsdossiers (De Ville, 2012). Nu de EU exclusief bevoegd is over handel, worden de lidstaten niet langer vereist om elk afzonderlijk de onderhandelde vrijhandelsakkoorden te ratificeren, tenzij het om een overeenkomst gaat die als 'gemengd' geldt, omdat er bepalingen in staan waarover de EU slechts deels bevoegd is. Concreet betekent dit dat het (sub)nationale niveau onder het Verdrag van Lissabon een groot deel van zijn parlementaire controle over het EU-handelsbeleid verliest, weliswaar ten voordele van het Europees Parlement, dat meer wetgevende bevoegdheid over handel krijgt toevertrouwd (De Ville 2012; Fritz, 2010, pp. 20-22; Ulmer, 2010).

Handelsexperten en beleidsmakers beschouwen deze verandering onder het Verdrag van Lissabon als een win-winsituatie, aangezien volgens hen niet alleen de efficiëntie maar ook de legitimiteit van het EU-handelsbeleid versterkt wordt (zie bv. Kleimann, 2011; Woolcock, 2010, p. 14). Doordat het Verdrag van Lissabon de bevoegdheden van het Europees Parlement als medewetgever en politiek controleorgaan aanzienlijk verruimt, staat het volgens hen buiten kijf dat het Verdrag het EU-handelsbeleid democratischer maakt. Vanuit puur handelsperspectief kan dit misschien een goede zaak zijn, namelijk omdat het EU-niveau verondersteld wordt het meeste inzicht te hebben in handelsaangelegenheden en het Europees Parlement hierdoor dus meer legitimiteit ter zake geniet dan de (sub)nationale parlementen. Dit belet echter niet dat de trade-off (waarrond subsidiariteit draait in handelsbeleid) tussen enerzijds de voordelen van vrijhandel en anderzijds de sociale doelstellingen en gevolgen die aan handel verbonden zijn, door de hervormingen onder het Lissabon-verdrag in het nadeel uitdraait van laatstgenoemde, doordat de (sub)nationale parlementen - die verondersteld worden meer geschikt te zijn om over sociale doelstellingen te beslissen en dus een grotere legitimiteit ter zake genieten - schaakmat zijn gezet.

Wij zien in deze recente hervormingen dan ook een verderzetting van de neoliberaal gestuurde tendens binnen de EU om het handelsbeleid verder te depolitiseren en te de-democratiseren, met name door het (sub)parlementaire niveau volledig de controle over handelsbeleid te ontzeggen, zodat de beoogde handelsliberalisering minder hoeft te vrezen voor marktbeperkende sociale doelstellingen. Deze bevinding sluit aan bij het neomarxistisch geïnspireerde argument van Bailey en Bossuyt (2012) dat de EU niet in staat is om een normatieve handelsagenda te verwezenlijken. Zoals we hierboven gezien hebben, staat het EU-handelsbeleid volgens de auteurs onder druk om verdere handelsliberalisering en marktexpansie na te streven, waardoor het zich genoodzaakt ziet om het beleid verder te depolitiseren (Bailey \& Bossuyt, 2012). Dit betekent dat de politieke elites, om hierin te slagen, moeten proberen om democratische participatie in en maatschappelijke mobilisering tegen het handelsbeleid te verhinderen of op zijn minst te beperken. Bailey en Bossuyt (2012) stellen dat de institutionele 
configuratie van het EU-handelsbeleid - dat weinig inspraak in en geringe controle van de burgers en zelfs van verkozen politici duldt over zijn besluitvorming - op verschillende manieren toelaat om zo'n uitkomst te garanderen. Orbie (2008, p. 62) van zijn kant wijst erop dat de Europese Commissie, waaraan het EU-handelsbeleidssysteem veel macht en belang verleent, automatisch voorrang geeft aan marktversterkende (waaronder regulerende niet-interventionistische) doelstellingen, eerder dan aan marktcorrigerende, interventionistische doelstellingen.

\section{Handelsbeleid onder het Verdrag van Lissabon: versterking of verzwakking van de democratische input?}

In wat volgt gaan we met behulp van de kritische inzichten die we hierboven verworven hebben concreet na of het Verdrag van Lissabon de (negatieve) impact van MLG op de democratische input in het EU-handelsbeleid versterkt of verzwakt. We richten ons hierbij op twee recentelijk afgesloten vrijhandelsakkoorden, met name het akkoord met Centraal-Amerika en het akkoord met Colombia en Peru. Om de impact op de inspraak van (sub)nationale parlementen te kunnen onderzoeken wordt aandacht besteed aan de parlementen van vijf lidstaten, namelijk Duitsland, het Verenigd Koninkrijk, België, Ierland en Nederland. Opdat de selectie van lidstaten voldoende representatief zou zijn voor de totale 'populatie' van EUlidstaten en om de mogelijke invloed van andere verklarende factoren uit te sluiten of te beperken, werd er bij de selectie voor gezorgd dat er voldoende variatie is op een aantal belangrijke variabelen: (i) omvang van handelsbelangen: lidstaten met aanzienlijke handelsbelangen in de respectievelijke handelspartners (Verenigd Koninkrijk, Duitsland en Nederland) versus lidstaten met geringe handelsbelangen in de respectievelijke landen (Ierland en België); (ii) staatsstructuur: federale staten (Duitsland, België en Verenigd Koninkrijk) ${ }^{1}$ versus eenheidsstaten (Ierland en Nederland); en (iii) substatelijke bevoegdheid inzake handel: lidstaten waarvan (bepaalde) deelstaten exclusief bevoegd zijn voor handel (België) versus lidstaten waarvan de deelstaten niet (of niet exclusief) bevoegd zijn voor handel (Duitsland en Verenigd Koninkrijk).

\subsection{De nieuwe generatie handelsakkoorden van de EU}

Het akkoord dat de EU onderhandeld heeft met Colombia en Peru is de tweede handelsovereenkomst, na het akkoord met Zuid-Korea, die de EU afsloot sinds de inwerkingtreding van het Verdrag van Lissabon. Het associatieakkoord tussen de 
EU en de landen van Centraal-Amerika ${ }^{2}$ is op zijn beurt de eerste associatieovereenkomst die de EU succesvol heeft afgerond sinds de inwerkingtreding van het Verdrag. De aanzet tot het onderhandelen van deze nieuwe reeks bilaterale en regionale handelsovereenkomsten werd gegeven in de Mededeling 'Global Europe' waarmee het Directoraat-Generaal Handel (DG Handel) in 2006 naar buiten kwam om de competitiviteit van de Europese economie via het handelsbeleid te vergroten. Terwijl de nieuwe strategie vooral de groeimarkten in Azië viseerde, bracht de lancering van de strategie de bestaande plannen om de Europese markttoegang tot de regionale markten van de Andesgemeenschap ${ }^{3}$ en Centraal-Amerika te verbeteren in een stroomversnelling. Bijgevolg werden de onderhandelingsmandaten voor het handelsluik van de associatieakkoorden met de respectievelijke regio's heel gelijkaardig aan de mandaten die de Raad goedkeurde voor de onderhandelingen met de Aziatische handelspartners. Terwijl de biregionale onderhandelingen met Centraal-Amerika goed vlotten, moesten de onderhandelingen met de Andesgemeenschap al gauw worden stilgelegd wegens interne verdeeldheid binnen het Andesblok over enkele van de door de EU voorgestelde bepalingen in het handelsluik van het akkoord. Belust op de voordelen die het handelsluik kon opleveren, keurde de Raad het voorstel van het DG Handel goed om het handelsluik af te splitsen van het associatieakkoord en zo een apart multipartiete handelsovereenkomst te onderhandelen met de Andeslanden die dit wilden, in casu Peru en Colombia.

Eigen aan de nieuwe generatie van bilaterale en regionale handelsakkoorden van de EU is dat ze thema's aanboren die - in de woorden van het DG Handel - 'nog niet rijp zijn voor multilaterale onderhandelingen' (Europese Commissie, 2006, p. 10). Ze worden 'WTO-plus-akkoorden' genoemd, omdat ze verder gaan dan de marktopening die momenteel in het kader van de WTO kan worden bereikt. Naast de afschaffing van invoerrechten op goederen en een verregaande vrijmaking van de handel in diensten bevatten deze overeenkomsten bepalingen over investeringen (in de diensten- en de industriële sector) en strenge regels inzake niet-handelsaspecten zoals openbare aanbestedingen, de bescherming van intellectuele eigendom (inclusief geografische aanduidingen), mededingingsregels, transparantie van de regelgeving en duurzame ontwikkeling.

De onderhandelingen met Peru en Colombia en de Centraal-Amerikaanse landen zijn beide tijdens het Spaanse EU-Voorzitterschap in 2010 afgerond. In 2011 werden de overeenkomsten door de hoofdonderhandelaars geparafeerd en in de loop van 2012 zullen ze, nadat zij ondertekend zijn, ter goedkeuring voorgelegd worden aan de Raad en vervolgens aan het Europees Parlement. 


\subsection{Democratische input in de handelsovereenkomsten met Colombia en Peru en Centraal-Amerika}

\subsubsection{Maatschappelijke participatie}

De aanpak van de Europese Commissie ten aanzien van maatschappelijke participatie zowel in de aanloop naar de twee akkoorden als tijdens de onderhandelingen laat weinig aan de verbeelding over in die zin dat de participatie van maatschappelijke actoren vrij hoog was maar dat de toegang tot die participatie duidelijk discrimineerde tussen commerciële belangengroepen en niet-commerciële belangengroepen. Dat commerciële belangengroepen bevoordeelde participatie genieten in het EU-handelsbeleid is niet nieuw. Zoals Siles-Brügge (2010) illustreert, zijn commerciële pro-liberaliseringsbelangengroepen (met andere woorden vooral exportgerichte belangengroepen) sinds de lancering van de Markttoegangstrategie van de Europese Commissie in 1996 geleidelijk aan steeds meer betrokken bij het handelsbeleid. Zoals de auteur aangeeft, "one of the cornerstones of this new strategy was a concerted effort on behalf of the Commission to involve business interests in policy-making. [...] This allowed, in the light of the Market Access Strategy's emphasis on engagement with pro-liberalization business groups, the services lobby to emerge as a key player in trade policy-making, which came to be closely allied to policy-makers in the Commission" (Siles-Brügge, 2010, p. xx; zie ook Dür, 2008a; 2008b). Zowel tijdens het draftingproces van de Global Europe-strategie (Siles-Brügge, 2010) als tijdens de respectievelijke handelsgesprekken (Eberhardt \& Dharmendra, 2010) konden deze exportgeörienteerde, pro-liberaliseringbelangengroepen, waaronder BusinessEurope en het European Services Forum, steunen op hun bevoordeelde toegang tot het beleidsapparaat via de informele contactfora en netwerken die ze in de loop der jaren hebben opgebouwd met het DG Handel.

De participatiekanalen van niet-commerciële belangengroepen, daarentegen, waren grotendeels beperkt tot de Civil Society Dialogue, een geïnstitutionaliseerd contactforum van het DG Handel waarin maatschappelijke organisaties en belangengroepen geraadpleegd worden over bepaalde thema's van het handelsbeleid. Buiten dit geïnstitutionaliseerde contactforum werden de visies van de niet-commerciële belangengroepen grotendeels genegeerd, inclusief die van Europese ngo's en overkoepelende vakbondgroeperingen, waaronder European Trade Union Confederation (ETUC), die in Brussel gevestigd zijn specifiek om bij de EU-instellingen te lobbyen. Ondanks de talrijke campagnes en mobilisering van een groot aantal maatschappelijke organisaties die hun bezorgdheid uitten ten aanzien van de mogelijke schadelijke impact van de handelsovereenkomsten voor het milieu, de duurzame ontwikkeling en de sociale context in de betrokken Latijns-Amerikaanse partnerlanden, hebben de organisaties in kwestie weinig of geen impact gehad op de beleidsagenda in verband met de handelsovereenkomsten (Agence Europe, 
2010a; Bossuyt, 2009; Eberhardt \& Dharmendra, 2010; Olivet \& Novo, 2011; Specht, 2006). Ook pogingen van maatschappelijke groeperingen uit Latijns-Amerika, waaronder Enlazando Alternativas, ${ }^{4}$ om de mogelijk destructieve impact van deze 'neoliberale' handelsovereenkomsten op hun fragiele micro-economie en samenleving aan de kaak te stellen, werden door het DG Handel genegeerd (Fritz, 2010; Icaza, 2010).

\subsubsection{Parlementaire inspraak}

Zoals reeds vermeld, is de macht van het Europese Parlement inzake handel aanzienlijk versterkt onder het Verdrag van Lissabon. Het Parlement is 'mede-beslisser' over het handelsbeleid, samen met de Raad. Terwijl het vroeger de Raad was en alle lidstaten afzonderlijk die een handelsovereenkomst moesten raticiferen, is die bevoegdheid nu in handen van de Raad en het Europees Parlement. Het kan niet ontkend worden dat die verhoogde macht voor het Europees Parlement het democratisch gehalte van het debat op EU-niveau versterkt. De europarlementariërs hebben dan ook niet nagelaten om zich een kritische houding aan te meten ten aanzien van het multi-partiete handelsakkoord met Peru en Colombia, dat volgens hen niet voldoende aandacht schenkt aan de erbarmelijke mensenrechtensituatie in Colombia (zie bv. Agence Europe, 2010c). Hoewel dit pas het tweede handelsakkoord is dat afgesloten is sinds de inwerkingtreding van het Lissabon-verdrag en het af te wachten valt hoe het Parlement zich ten aanzien van andere handelsakkoorden zal positioneren, voedt de kritische houding van het Parlement inzake mensenrechten in het Colombia-akkoord bij velen de verwachting dat het EU-handelsbeleid meer gepolitiseerd zal worden nu het Europees Parlement meer zeggingschap heeft over handel (bv. Kleimann, 2011). Dit doet volgens ons echter niets af aan de redenering dat de hervormingen onder het Lissabon-verdrag kaderen binnen een geleidelijke (neoliberaal gestuurde) trend om het handelsbeleid verder te de-politiseren en te de-democratiseren door het volledig over te hevelen naar het EU-niveau. Onze redenering heeft namelijk vooral betrekking op de onderliggende sociale strijd die aan de bevoegdheidbeslissingen binnen het MLG-systeem voorafgaat en, in het geval van het EU-handelsbeleid, op de sociale dimensie van handel. Zoals we hierboven geargumenteerd hebben, is het Europese Parlement niet het meest geschikte parlementaire forum om te beslissen over de sociale doelstellingen en gevolgen die aan handel gekoppeld zijn. Doordat de beleidsaspecten die de welvaartstaat in stand houden (begroting, fiscaal beleid, werkgelegenheid, ...) een aangelegenheid zijn van de lidstaten, staat het Europees Parlement niet dicht genoeg bij de burgers om voldoende geïnformeerd te zijn over de mogelijk uiteenlopende maatschappelijke preferenties ten aanzien van de negatieve sociale impact die ongebreidelde vrijhandel met zich mee kan brengen, en kan het dus niet voldoende legitimiteit 
garanderen op het vlak van de sociale dimensie van het handelsbeleid, iets wat de (sub)nationale parlementen wel zouden kunnen (De Ville, 2012).

De parlementaire discussies binnen het Europees Parlement over de handelsakkoorden met Colombia en Peru en Centraal-Amerika lijken deze assumptie te bevestigen. Terwijl bezorgdheid over de mogelijke schadelijke gevolgen van het handelsakkoord met Centraal-Amerika voor de fragiele Centraal-Amerikaanse economieën en eco-systemen nog prominent aanwezig was in de parlementaire resolutie in 2007 over het onderhandelingsmandaat van de Europese Commissie voor het akkoord, mede door toedoen van de fractie van de Groenen, is deze bezorgdheid vandaag veel minder hoorbaar in het Europees halfrond (European Parliament, 2007; Agence Europe, 2010c; persoonlijk interview, 20 januari 2012). De verwachting is dan ook dat het akkoord zonder al te veel tegenstemmen zal worden goedgekeurd, ondanks de talrijke pogingen van maatschappelijke organisaties om het Parlement bewust te maken van de mogelijke negatieve impact op de partnerlanden (persoonlijk interview, 20 januari 2012). Dit suggereert heel ostentatief dat het Parlement - in navolging van zijn ratificatie van het akkoord met Zuid-Korea - grotendeels instemt met de sterke pro-handelsliberaliseringsagenda die het DG Handel voor de EU heeft uitgestippeld. Dit wordt enkel bevestigd wat het akkoord met Colombia en Peru betreft, al is de toekomst van dit akkoord minder sterk verzegeld omwille van de aanhoudende oppositie in het Parlement inzake het mensenrechtenaspect van het akkoord. Ook hier blijkt namelijk dat slechts een beperkt aantal, vooral linksgezinde, parlementsleden blijven stilstaan bij de sociale implicaties van het akkoord, ondanks verwoede pogingen van ontwikkelingsngo's om hierover een groter debat te voeren (persoonlijk interview, 20 januari 2012).

Als het Europees Parlement aldus niet voldoende legitimiteit kan garanderen op het vlak van de sociale dimensie van het handelsbeleid, dan zouden de (sub)nationale parlementen dat moeten kunnen (De Ville, 2012). Terwijl de (sub)nationale parlementen de vaak bijzonder technische aspecten van handelsbeslissingen en wederzijdse toegevingen inzake markttoegang zouden kunnen of moeten overlaten aan het EU-niveau, dat het meest geschikte niveau is om efficiënt en doeltreffend met deze handelsdoelstellingen om te gaan, zouden ze hun rol moeten opnemen als democratische instelling waar het vereiste debat plaatsvindt over de kwestie hoe handelsbeleid zich verhoudt tegenover het sociale doel dat democratische samenlevingen voor zichzelf voor ogen hebben (De Ville, 2012). Uit ons eigen onderzoek bij vijf lidstaten blijkt dat de meeste parlementen effectief deze rol willen opnemen, of beter: 'terugeisen'. Inderdaad, in vier van de vijf onderzochte lidstaten, namelijk in Duitsland, Nederland, Ierland en het Verenigd Koninkrijk, hebben de bevoegde parlementen pogingen ondernomen (meer bepaald door een motie in te dienen en door verschillende parlementaire discussies) om de besluitvorming over het vrijhandelsakkoord met Peru en Colombia terug te politiseren of te democrati- 
seren, door via hun regering de EU te verzoeken om het akkoord als 'gemengd' te doen gelden, zodat het ter ratificatie wordt voorgelegd aan de parlementen van de lidstaten en ze de kans krijgen om te delibereren over de niet-handelsgerelateerde aspecten van het akkoord (Deutscher Bundestag, 2010; Irish Dáil 2010, 2011; Olivet \& Novo, 2011, p. 2; Tweede Kamer der Staten-Generaal, 2011; UK Parliament, 2010). In de motie die door Duitse parlementsleden werd ingediend, bijvoorbeeld, riep men de Bundestag op “om zijn wetgevende plicht op te nemen en te eisen dat het een beslissing kan nemen over de ratificatie van het vrijhandelsakkoord tussen de EU en Colombia en Peru, dat niet louter handelsaangelegenheden aangaat maar ook zaken over structureel, grondwettelijk en mensenrechtenbeleid” (Deutscher Bundestag 2010).

Hoewel het DG Handel tot op het laatste moment is blijven volharden dat het akkoord met Colombia en Peru een puur vrijhandelsakkoord is en het dus niet nodig was om het als 'gemengd' te doen kwalificeren, is de Raad ingegaan op het verzoek van verschillende nationale parlementen om de precieze aard van het akkoord te doen bepalen door daartoe aangestelde juristen uit het juridische comité van de Raad. Het juridische advies luidde dat het om een gemengd akkoord ging. Maar nog voor de Raad in december 2011 het juridische advies opvolgde en unaniem besliste dat het akkoord effectief als gemengd moest worden gekwalificeerd, rees er al een nieuwe bezorgdheid onder verschillende nationale parlementen, dit keer over de optie van 'voorlopige inwerkingtreding' van het vrijhandelsakkoord (bv. Irish Dáil, 2010, 2011; Tweede Kamer der Staten-Generaal, 2011). Het akkoord met Colombia en Peru - net als de andere nieuwe EU-vrijhandelsakkoorden voorziet namelijk in de mogelijkheid om voorlopig ofwel geheel ofwel gedeeltelijk in werking te treden in afwachting van de ratificatie van het akkoord door het Europees Parlement en de (sub)nationale parlementen. De optie van voorlopige toepassing, die voor het eerst werd gebruikt bij het akkoord met Zuid-Korea, werd door de EU geïntroduceerd om te vermijden dat men door de soms jarenlang slepende parlementaire ratificatieprocedures naast de aanzienlijke commerciële voordelen grijpt die het akkoord kan opleveren. Als het Europees Parlement het akkoord niet goedkeurt, eindigt de voorlopige toepassing voor de EU als geheel. Als een (sub) nationaal parlement het akkoord niet goedkeurt, eindigt de voorlopige toepassing van het akkoord enkel voor wat betreft deze lidstaat of regio. Maar de betreffende lidstaat of regio is dan nog steeds gebonden aan de bepalingen in het handelsakkoord die vallen onder exclusieve EU-bevoegheden, kortom het merendeel van de bepalingen. Het lijkt ons vrij duidelijk wat die optie van voorlopige toepassing betekent in termen van de trade-off tussen (economische) efficiëntie en legitimiteit. 


\section{Slotopmerkingen}

Dit artikel had tot doel de impact te onderzoeken van MLG op de democratische input in het EU-handelsbeleid onder het Verdrag van Lissabon en vertrok daarbij vanuit de vaststelling van Peters en Pierre (2004, p. 75) dat er behoefte is aan een kritische discussie van MLG als democratisch proces. MLG als bestuurssysteem houdt namelijk een aantal gevaren en risico's in voor democratische verantwoording en participatie, die onder meer voortkomen uit het sterk 'output'-gerichte karakter van MLG en de nadruk op technische efficiëntie.

Het voornaamste besluit van het artikel is dat de dominante aanname in de literatuur dient te worden genuanceerd, namelijk de intussen wijdverspreide assumptie dat het Verdrag van Lissabon het democratische gehalte van het EU-handelsbeleid versterkt door het Europees Parlement meer wetgevende bevoegdheid te geven inzake handel. De toegenomen wetgevende bevoegdheid van het Europees Parlement komt ten gunste van de democratische input in het beleid, maar enkel in de zin dat het EU-niveau het meest geschikt is om efficiënt en doeltreffend om te gaan met de technische, economische aspecten van het handelsbeleid. Het Europees Parlement geniet namelijk minder legitimiteit als het om de sociale doelstellingen en gevolgen van handel gaat, in tegenstelling tot de (sub)nationale parlementen. Doordat de beleidsaspecten die de welvaartstaat in stand houden een aangelegenheid zijn van de lidstaten, staat het Europees Parlement niet dicht genoeg bij de burgers om voldoende geïnformeerd te zijn over de mogelijk uiteenlopende maatschappelijke preferenties ten aanzien van de negatieve sociale impact die ongebreidelde vrijhandel met zich mee kan brengen.

Zoals we in het geval van de handelsakkoorden met Colombia-Peru en CentraalAmerika geobserveerd hebben, betekent de verdere machtsverschuiving naar het EU-niveau inzake handelsbeleid ook dat de participatie van niet-statelijke actoren enerzijds beperkt blijft, in het bijzonder voor niet-commerciële belangengroepen, en anderzijds discriminerend, met name ten gunste van commerciële belangengroepen. Dit sluit aan bij het argument dat de verhouding tussen de bestuursniveaus - of 'schalen' - binnen het MLG-systeem geen natuurlijk gegeven is maar het gevolg is van eerdere sociale verhoudingen en strijd, niet in het minst tussen kapitaal en arbeid. Hierbij wordt kapitaal in het MLG-systeem bevoordeeld dankzij zijn relatieve mobiliteit en zijn vermogen om op verschillende niveaus (lobby) middelen in te zetten, in tegenstelling tot arbeid die relatief verankerd zit op het (sub)nationale niveau en niet over de capaciteit beschikt om het EU-niveau danig te beïnvloeden.

Anders gezegd: de gevaren en risico's van MLG als bestuurssysteem verbergen een meer diepgaande tendens die gekenmerkt wordt door een uitdrukkelijke (neoliberaal gestuurde) poging om de Europese politieke besluitvorming te depolitiseren, of te 'de-democratiseren'. Via de verplaatsing van de besluitvorming 
naar het supranationale niveau, waar democratische participatie geconfronteerd wordt met verschillende obstakels, slagen de Europese politieke elites erin om de ruimte voor (mogelijk tegenwerkende) democratische participatie te beperken. Dit proces van de-democratisering is verbonden met de marktgerichte, neoliberale agenda die domineert op het EU-niveau. Vanuit dit opzicht kan de EU zelfs beschouwd worden als een poging van de Europese politieke elite om haar greep op de Europese maatschappij veilig te stellen door het toepassen van een gededemocratiseerde vorm van democratie die grotendeels bestuurd wordt door de bevordering van het marktmechanisme als basisbeginsel voor de regulering van sociale interactie.

\section{Noten}

1. Formeel is het Verenigd Koninkrijk in principe een eenheidsstaat, maar de facto is het een federale staat.

2. De groep van Centraal-Amerikaanse landen omvat Costa Rica, Panama, Guatemala, Honduras, El Salvador en Nicaragua.

3. De Andesgemeenschap bestaat uit Bolivia, Colombia, Ecuador en Peru.

4. http://www.enlazandoalternativas.org/IMG/pdf/ea-en.pdf.

\section{Bibliografie}

Agence Europe (2010a). South American NGOs Say Human Rights Need Greater Protection in EU Free Trade Deals with Colombia and Peru, 19 March.

Agence Europe (2010b). European Parliament Plenary Session, 24 April.

Agence Europe (2010c). Greens Criticise Free Trade Agreements with Central America, Colombia and Peru, 20 May.

Bache, I. \& Flinders, M. (2004a). Conclusions and Implications. In I. Bache \& M. Flinders (eds.), Multi-level Governance (pp. 195-206). Oxford: Oxford University Press.

Bache, I. \& Flinders, M. (eds.) (2004b). Multi-level Governance. Oxford: Oxford University Press.

Bailey, D.J. (2010). The European Rescue, Recommodification, and/or Reterritorialization of the (Becoming-Capitalist) State? Marx, Deleuze, Guattari, and the European Union. Journal of International Relations and Development, 13 (4), 325-53. 
Bailey, D.J. \& Bossuyt, F. (2012). The European Union as a Conveniently Conflicted Counter-hegemon through Trade. Journal of Contemporary European Research, 8 (2), forthcoming.

Bellone, C. \& Goerl, G. (1992). Reconciling Public Entrepreneurship and Democracy. Public Administrative Review, 52 (2), 130-34.

Bonefeld, W. (2001). European Monetary Union: Ideology and Class. In W. Bonefeld (ed.), The Politics of Europe: Monetary Union and Class (pp. 64-106). Basingstoke: Palgrave.

Bossuyt, F. (2009). The Social Dimension of the New Generation of EU Free Trade Agreements with Asia and Latin America: Ambitious Continuation for the Sake of Policy Coherence. European Foreign Affairs Review, 14 (5), 703-742.

Bovens, M., Curtin, D. \& 't Hart, P. (eds.). (2010). The Real World of EU Accountability. What Deficit? Oxford: Oxford University Press.

Boyer, R. (2011). Are there Laws of Motion of Capitalism? Socio-Economic Review, 9 (1), 59-81.

Bursens, P. \& Baetens, M. (2006). Transformatie van soevereiniteit door Europese integratie. Op zoek naar de legitimiteit van een meerlagig politiek systeem. In M. Hooghe (ed.), Op zoek naar politiek. Democratie en de verplaatsing van de politiek (pp. 65-84). Leuven: Acco.

Bursens, P. \& Wouters, J. (2001). De Verklaring van Laken en daarna: Institutionele aspecten van het 'post-Nice' proces', Instituut voor Internationaal Recht, Working Paper, Nr. 1, Mei, Online raadpleegbaar via https://www.law.kuleuven.be/iir/nl/ onderzoek/wp/WP01n.pdf.

Deutscher Bundestag (2010). Freihandelsabkommen EU Kolumbien-Peru: Mitwirkungsrechte des Deutschen Bundestags sichern. Deutscher Bundestag, Fraktion DIE LINKE, Drucksache 17/1970, 9 juni.

De Ville, F. (2012). Subsidiarity and EU Trade Policy: Overview of the Complex Discussion, Treaty of Lisbon, and Implications for Flanders. In J. Loisen \& F. De Ville (eds.), Subsidiarity and Multilevel Governance (in druk). Brussel: KVAB.

Devos, C. (2001). Machtsrelevantie van multi-level structuren: een algemene verkenning. Res Publica, 43 (1), 81-101.

Dür, A. (2008a). Bringing Economic Interests Back into the Study of EU Trade PolicyMaking. British Journal of Politics and International Relations, 10 (1), 27-45.

Dür, A. (2008b). Interest Groups in the European Union: How Powerful Are They? West European Politics, 31 (6), 1212-1230.

Dür, A. (2010). Protection for Exporters: Power and Discrimination in Transatlantic Trade Relations, 1930-2010. Ithaca: Cornell University Press.

Dür, A. \& De Bièvre, D. (2007). Inclusion without Influence? NGOs in European Trade Policy. Journal of Public Policy, 27 (1), 79-101. 
Eberhardt, P. \& Dharmendra, K. (2010). Trade Invaders: How Big Business is Driving the EU-India Free Trade Negotiations. Brussels: Corporate Europe Observatory; Delhi: India FDI Watch.

Enlazando Alternativas, http://www.enlazandoalternativas.org/IMG/pdf/ea-en.pdf.

European Commission (2006). Global Europe: Competing in the World, Brussels, 4 October, http://trade.ec.europa.eu/doclib/docs/2006/october/tradoc_130376.pdf.

European Parlement (2007). European Parliament Recommendation of 15 March 2007 to the Council on the Negotiating Mandate for an Association Agreement between the European Union and its Member States, of the One Part, and the Countries of Central America, of the Other Part, 2006/2222(INI), Strasbourg, 15 March.

Fritz, T. (2010). The Second Conquest - The EU Free Trade Agreement with Colombia and Peru. Berlin: FDCL; Amsterdam: TNI.

Greven, M.T. (2005). The Informalization of Transnational Governance: A Threat to Democratic Government. In E. Grande \& L.W. Pauly (eds.), Complex Sovereignty. Reconstituting Political Authority in the Twenty-first Century (pp. 261-284). Toronto: University of Toronto Press.

Hannah, E.N. (2011). NGOs and the European Union: Examining the Power of Epistemes in the EC's TRIPS and Access to Medicines Negotiations. Journal of Civil Society, 7 (2), 179-206.

Harlow, C. \& Rawlings, R. (2006). Promoting Accountability in Multi-Level Governance: A Network Approach. European Governance Papers. No. C-06-02. Online raadpleegbaar via www.connex-network.org/eurogov/pdf/egp-connex-C-06-02.pdf.

Harmes, A. (2006). Neoliberalism and Multilevel Governance. Review of International Political Economy, 13 (5), 725-749.

Hooghe, L. \& Marks, G. (2001). Multi-level Governance and European Integration. Lanham: Rowman \& Littlefield.

Icaza, R. (2010). Global Europe, Guilty! Contesting EU Neoliberal Governance for Latin America and the Caribbean. Third World Quarterly, 31 (1), 123-139.

International Trade Committee of the European Parliament (INTA) (2010). Discussion on the EU Trade Agreement with Colombia and Peru between Trade Commissioner Karel De Gucht and INTA, 16 March.

Irish Dáil (2010). Written Answers in Dáil, 24 June, Question 179, raised by Michael D Higgins (Galway West, Labour), 27381/10.

Irish Dáil (2011). Priority Questions, 20 January, Question 2, raised by Michael D Higgins (Galway West, Labour), 2996/11.

Jarman, H. (2008). The Other Side of the Coin: Knowledge, NGOs and EU Trade Policy. Politics, 28 (1), 26-32.

Kleimann, D. (2011). Taking Stock: EU Common Commercial Policy in the Lisbon Era, CEPS Working Document, No. 345, April.

Klemmt, M. (2011). Business Interests before Human Rights. The EU Free Trade Agreement with Colombia, Position Paper, Forum Umwelt und Entwicklung, Misereor, 
Oxfam Deutschland e.V., WEED e.V., Online raadpleegbaar via http://www.docs. forumue.de/positionspapiere/FS_ColombiaENG.pdf.

Lord, C. \& Harris, E. (2006). Democracy in the New Europe. Basingstoke: Palgrave.

Mair, P. (2005). Popular Democracy and the European Union Polity, European Governance Papers, No. C-05-03, Online raadpleegbaar via http://www.connex-network. org/eurogov/pdf/egp-connex-C-05-03.pdf.

Mair, P. (2007). Political Opposition and the European Union. Government and Opposition, 42 (1), 1-17.

Moe, R. (1994). The 'Reinventing Government' Exercise. Public Administration Review, 54 (2), 111-122.

Olivet, C. \& Novo, P. (2011). Time for Europe to Put Values and Human Rights above Commercial Advantage. Why EU-Colombia/Peru Free Trade Agreements Should not be Ratified, Policy Brief, Transnational Institute, March.

Orbie, J. (2008). The European Union's Role in World Trade: Harnessing Globalisation? In J. Orbie (ed.), Europe's Global Role (pp. 35-66). London: Asghate.

Oughton, D. (1995). Accountability versus Control - Rust never Sleeps. Public Sector, 17 (3), 2-6.

Perraton, J. \& Wells, P. (2004). Multilevel Governance and Economic Policy. In I. Bache \& M. Flinders (eds.), Multi-level Governance (pp. 179-194). Oxford: Oxford University Press.

Peters, G. \& Pierre, J. (2004). Multi-level Governance and Democracy: A Faustian Bargain? In I. Bache \& M. Flinders (eds.). Multi-level Governance (pp. 75-91). Oxford: Oxford University Press.

Rancière, J. (2006). Hatred of Democracy. London: Verso.

Roth, D. (1996). Finding the Balance: Achieving a Synthesis between Improved Performance and Enhanced Accountability. In OECD Performance Auditing and the Modernisation of Government (pp. 249-259). Paris: OECD.

Shields. S. (2011). From the Washington Consensus to the Brussels Consensus ... and beyond: Neoliberalisation by Depoliticisation in Post-communist Poland. Socialism and Democracy, 25 (2), 81-103.

Siles-Brügge, G. (2010). Bringing Politics Back in: Economic Interests and the Shift Toward Bilateralism in EU Trade Policy. Paper presented at the ECPR 'Fifth Pan-European Conference on EU Politics', Porto, 24-26 June.

Specht, B. (2006). Mandelson Trades away Gender Justice and Sustainable Development: New EC Communication: Global Europe: Competing in the World', No. 9, WIDE News.

Streeck, W. (2011). Taking Capitalism seriously: Towards an Institutionalist Approach to Contemporary Political Economy. Socio-Economic Review, 9 (1), 137-67.

Tweede Kamer der Staten-Generaal (2011), Online raadpleegbaar via https://zoek.officielebekendmakingen.nl/kst-21501-02-1062.html, 27 april 2011. 
UK Parliament (2010). Early Day Motion 261, EU Free Trade Agreement with Colombia and Peru. London, 16 June, Online raadpleegbaar via http://www.parliament.uk/ edm/2010-11/261.

Ulmer, K. (2010). EU Trade Policy under Lisbon Treaty. APRODEV Brief, March.

Vlaamse Regering (2009). Beleidsnota 2009-2014: buitenlands beleid, internationaal ondernemen en ontwikkelingssamenwerking.

Woolcock, S. (2010). The Treaty of Lisbon and the European Union as an Actor in International Trade. ECIPE Working Paper, 01/2010. 